\title{
A literature review on implant abutment and soft tissue response
}

\author{
Young-Hoon Lee, Kyung-Ho Ko, Yoon-Hyuk Huh, Chan-Jin Park, Lee-Ra Cho* \\ Department of Prosthodontics and Research Institute of Oral Science, College of Dentistry, Gangneung-Wonju National \\ University, Gangneung, Republic of Korea
}

In the implant prosthetic procedure, the soft tissue reaction was varied with the material and surface treatment of the abutment. It may be the cause of the peri-implantitis, and hence it can affect the long-term prognosis of the implant prosthesis. Titania and zirconia abutment presented superior biocompatibility and stable soft tissue reaction, while gold alloy abutment showed unfavorable reaction sometimes. A soft tissue reaction can be differed by the surface characteristics even in the same material type. Because rougher surface induces a bacterial attachment, the part contacting a soft tissue should have smooth surface. Additional surface treatment can enhance the cellular response without increasing bacterial attachment. Repeated removal and insertion of the abutment and the shape of the abutment may affect the soft tissue reaction, also. Ultrasonic cleaning and argon plasma cleaning are effective way to clean the retained micro-dust on the customized abutment. (J Dent Rehabil Appl Sci 2016;32(4):26373)

Key words: abutment material; surface treatment; cellular response; bacterial attachment; custom abutment

\footnotetext{
서론

임플란트를 장기간 성공적으로 유지하기 위해서는 변 연골의 안정성과 건강한 연조직 형성이 필수적이다. 임 플란트 지대주는 연조직과 접촉하여 구강환경으로부터 임플란트를 보호하므로 접합상피와 결합조직의 부착에 의한 적절한 생물학적 폭경 형성이 필요하다. Lindhe와 Berglundh ${ }^{1}$ 에 따르면 임플란트는 자연치와 유사하게 상 부의 부착상피와 하부의 결합조직 부착을 지니는데, 부 착상피는 $2 \mathrm{~mm}$ 정도이며 반교소체에 의해 지대주 표면 에 부착하고, 결합조직은 $1-1.5 \mathrm{~mm}$ 로 자연치와 다르게 콜라겐섬유가 수직적으로 연결되지 않고 평행하게 주행 한다고 한다(Fig. 1).

현재 일반적으로 사용되고 있는 임플란트 지대주의 재 료는 전통적인 주조방식을 사용하는 귀금속합금인 금합

*Correspondence to: Lee-Ra Cho

Professor, Department of Prosthodontics and Research Institute of Oral Science, College of Dentistry, Gangneung-Wonju National University, 7 Jukheon-gil, Gangneung, 25457, Republic of Korea

Tel: +82-33-640-3153, Fax: +82-33-640-3103, E-mail: lila@gwnu.ac.kr

Received: September 13, 2016/Last Revision: December 5, 2016/Accepted:

December 8, 2016
}

금(gold alloy)과 비귀금속합금(Co-Cr alloy)과, computer aided design/computer aided manufacturing (CAD/ CAM) 방식을 이용하는 지르코니아와 티타늄합금 등이 널리 사용되고 있다. 티타늄은 생체적합성이 우수한 생 체재료로 공기 중에서 산화되어 표면에 얇은 산화막을 갖게 된다. 티타늄 산화막에 의한 보호작용으로 부식에 높은 저항성을 가져 체내에서 안정적으로 사용할 수 있 다. 지르코니아는 티타늄보다 우수한 생체친화성을 가지 며 생체불활성 소재로 체내에서 독성이나 염증반응을 일 으키지 않으며 부식이나 변색에 대한 저항성이 매우 높 다. 이러한 지르코니아를 이용한 지대주는 재료 자체의 안정성뿐만 아니라 자연치아와 유사한 색상으로 기존의 금속 지대주를 사용했을 때 발생될 수 있는 치은주위 변 색을 막을 수 있어 심미적으로 많은 장점을 지닌다. ${ }^{2}$

이상적인 지대주 재료는 상피보호막(epithelial barrier)

CopyrightC 2016 The Korean Academy of Stomatognathic Function and Occlusion. (c) It is identical to Creative Commons Non-Commercial License. 
을 형성할 수 있도록 섬유아세포(fibroblast)와 상피세포 (epithelial cell)의 부착 및 증식을 유도하며, 임플란트 주 위염의 원인이 되는 세균막(biofilm)과 박테리아의 부착 은 최소화 할 수 있는 재료여야 한다. ${ }^{3}$

본 고찰에서는 현재 사용되고 있는 지대주의 재료에 따른 세포 및 연조직반응과 박테리아의 부착, 표면특성 의 개선을 위한 다양한 방법들에 대해 살펴보고 지대주 의 임상적인 특성 및 맞춤형 지대주에 대해 알아보고자 한다.

\section{지대주 재료에 대한 세포 및 연조직반응}

임플란트 지대주와 연조직의 계면은 두 가지 구역으로 구분할 수 있다. ${ }^{4,5}$ 상부는 접합상피로 치아주위의 상피 와 구조적, 기능적으로 유사하고 각화되어 있으며, 구강 상피-구강열구상피-접합상피로 연결된다. 접합상피는 반 교소체와 기저판을 이용해 지대주 표면에 부착하게 되며 이러한 상피조직에 의해 상피장벽을 형성하여 하방 조직 을 보호한다. 하부는 결합조직이 콜라겐 섬유를 형성해 부착하며 자연치와 달리 손상된 조직(scar-like tissue)의 특성을 보여 더 많은 콜라겐 섬유와 더 적은 섬유아세포

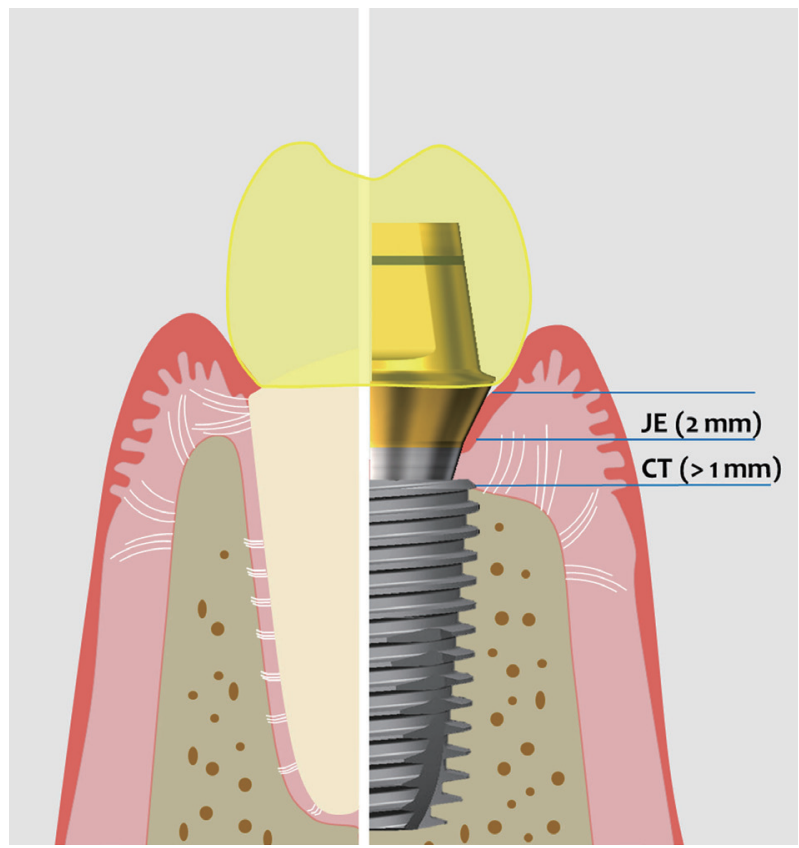

Fig. 1. Soft tissue surrounding tooth (left) and implant (right). Longer junctional epithelium (JE) and parallel arranged connective tissue (CT) fiber surrounding implant.
의 분포특성을 지닌다. 이로 인해 조직회복주기가 자연 치 주변 치은에 비해 길고, 결합상피 하방의 결합조직의 혈류공급이 줄어 세균성 치태에 대한 저항성이 상대적으 로 낮다(Fig. 1). 지대주 표면에 대한 연조직의 부착은 안 정적이고 건강한 점막봉쇄(mucosal seal)를 이루어 하방 연조직과 경조직을 보호하는 장벽역할을 한다. 연조직의 부착과정에서 우선 섬유아세포의 이주에 의해 콜라겐섬 유와 세포외기질(extra-cellular matrix)이 형성되고 케라 틴세포(keratinocyte)와 상피세포가 콜라겐섬유에서 각 질층을 형성하여 상피보호막을 형성한다. 이러한 장벽의 형성은 1 - 2주부터 시작되며 6-8주에 완료된다고 알려 져 있다. ${ }^{6}$

임플란트 주위 연조직은 치아주위 치주조직에 비해 박테리아의 축적에 상대적으로 취약할 뿐 아니라, 기계 적인 과부하, 보철적인 요인 등에 의해서도 영향을 받 게 된다. 연조직 부착의 질을 결정하는 지대주의 표면 요인인 표면의 화학적 특성과 표면에너지 및 표면형태 (topography) 등도 생체적합성에 영향을 준다. ${ }^{7}$ 이상적인 지대주는 섬유아세포와 상피세포의 부착에는 유리하지 만 세균막과 박테리아의 부착은 적어야 한다.

임플란트 지대주의 재료에 따른 세포반응에 관한 연구들을 살펴보면, Abrahamsson 등 ${ }^{7}$ 은 동물실험에 서 티타늄(commercially pure titanium), 세라믹( $\mathrm{Al}_{2} \mathrm{O}_{3}$ ceramics), 금합금 등 세 가지 재료의 지대주를 비교하였 다. 그 결과 티타늄과 세라믹은 유사한 점막부착과 조직 학적 소견을 보였지만, 금합금 지대주는 상대적으로 약 한 연조직 부착을 보여 치은퇴축과 변연골소실이 상대적 으로 크게 나타났다. 오랫동안 구강 내에서 유지된 금합 금 지대주와 티타늄 지대주의 반응을 보면 임상적으로 차이가 나는 경우가 많다(Fig. 2). 반면 Abrahamsson 등 ${ }^{8}$ 의 이후 연구에서는 티타늄 (grade 4 commercially pure titanium)과 금합금의 연조직반응을 비교하였을 때, 두 재료간에 연조직 부착길이는 유의한 차이가 없었다. ${ }^{8}$ 저 자는 이전 실험과 달리 두 종류의 재료가 적절한 표면거 칠기(smooth surface)를 가져 지대주의 상피세포의 부착 과 확산(spreading)이 양호하게 나타났다고 하였다. 이는 지대주에 대한 연조직반응이 재료의 종류뿐 아니라 표면 특성에 따라 달라질 수 있다는 것을 보여준다. Welander 등 ${ }^{9}$ 은 티타늄, 지르코니아, 금합금 3 가지 재료를 2개월에 서 5 개월까지 관찰하며 비교하였는데, 티타늄과 지르코 니아는 부착상피와 결합조직의 수직적인 부착길이가 유 지되었으나, 금합금에서는 접합상피의 퇴축 및 변연골 

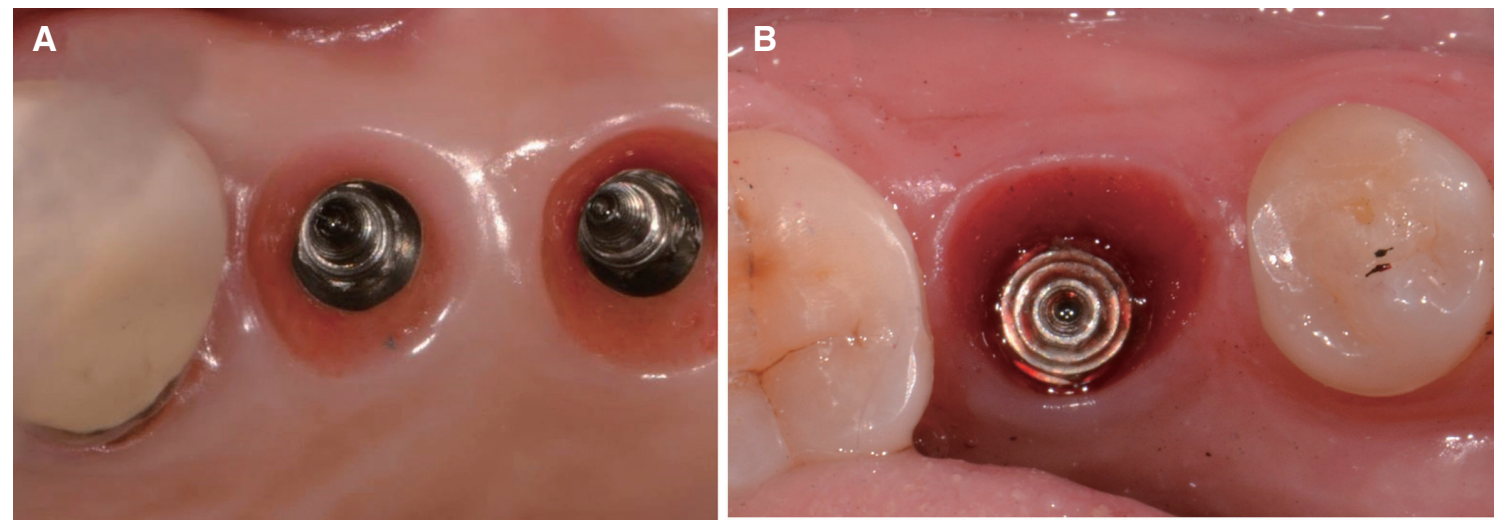

Fig. 2. Long-term soft tissue reaction on the different abutment materials. (A) Healthy soft tissue surrounding titanium abutment, (B) Inflammatory tissue surrounding gold abutment.

소실이 관찰되었으며 조직학적 관찰 시 금합금 표면에 서 콜라겐과 섬유아세포가 적고 백혈구는 상대적으로 많 이 관찰되는 불완전한 점막봉쇄를 형성하였다고 하였다. Van Brakel의 연구 ${ }^{10}$ 에서는 티타늄과 지르코니아의 조직 학적 소견을 비교하여 두 군간에 유의한 조직학적 차이 가 관찰되지 않고 건강한 임플란트 주위 연조직을 보였 다고 보고하였다.

표면거칠기에 따른 세포반응 연구를 살펴보면, Moon 등 $^{11}$ 은 티타늄과 지르코니아의 표면을 기계 절삭된 상태 의 거친 표면(rough surface)과 연마 시행한 평활한 표면 (smooth surface)으로 나누어 비교하였다. 주사전자현미 경 관찰 시 연마 시행한 평활한 티타늄 표면에서 섬유아 세포의 부착형태가 우수하게 관찰되었고 세포증식에서 는 절삭된 상태의 거친 표면에서 절삭선(machined line) 을 따라 증식하는 것 이외에는 모든 표면에서 유의한 차 이가 없었다. 표면이 거친 실험군에서는 세포부착력 평가 시에도 표면처리에 따른 유의한 차이가 관찰되지 않았 다. Nothdurft 등 ${ }^{12}$ 은 티타늄(Ti)과 지르코니아 $(\mathrm{Zr})$ 의 표 면거칠기( $\mathrm{Ra}$ 값으로 평가)를 달리하여 기계절삭한 표면 (Ti: $69 \mathrm{~nm}, \mathrm{Zr}: 198.8 \mathrm{~nm}$ ), 연마하여 평활한 표면(Ti: 69 $\mathrm{nm}$ ), 압축공기입자연마(airborne-particle abrasion) 시행 한 거친 표면(Ti: $1514 \mathrm{~nm}, \mathrm{Zr}: 1021 \mathrm{~nm})$ 에 대한 섬유아 세포와 상피세포의 반응에 대해 평가하였다. 연조직 부 착의 초기에 관여하는 것으로 알려진 섬유아세포의 증식 속도는 지르코니아 표면이 티타늄 표면보다 우수하게 나 타났다. 재료 내의 표면거칠기에 따른 비교 시 지르코니 아 표면에서는 거친 표면에서 더 높은 증식을 보이나 티
타늄 표면은 평활한 표면에서 더 높은 증식을 보여 표면 재료에 따라 표면거칠기가 세포반응에 미치는 영향이 상 이한 결과를 보였다. 상피세포는 압축공기입자연마를 시행한 거친 티타늄 표면에서 가장 높은 증식을 보였다. $\mathrm{Kim}$ 등 $^{13}$ 은 티타늄과 비귀금속합금(Co-Cr-Mo), 지르코 니아의 표면처리에 따른 치은섬유아세포의 반응을 조사 하였다. 표면거칠기의 경우 모두 평활한 표면 $(\mathrm{Sa}<0.5$ $\mathrm{nm}, \mathrm{Zr}: 19 \mathrm{~nm}$, composite resin coating on Ti : $390 \mathrm{~nm}$, 나머지 표본: 약 $220 \mathrm{~nm}$ )으로 세포반응에 영향을 미치 지 않았으며, 표면에너지를 나타내는 접촉각은 섬유아세 포의 부착 및 증식에 영향을 미치는데 낮은 접촉각을 갖 는 표면(TiN코팅한 티타늄, 양극산화한 티타늄, 지르코 니아)에서 우수한 세포반응을 보였다. 비귀금속합금(Co$\mathrm{Cr}-\mathrm{Mo})$ 표면은 상대적으로 적은 세포부착과 증식의 결과 를 보였다. Rutkunas 등 ${ }^{14}$ 은 티타늄, 지르코니아, 비귀금 속 합금 $(\mathrm{Cr}-\mathrm{Co}, 30 \mathrm{~nm})$, 금합금 $($ 약 $30 \mathrm{~nm})$ 의 4가지 재료 에 대해 비교하면서 이중 티타늄(연마처리: 약 $30 \mathrm{~nm}$, 압 축공기입자: $790 \mathrm{~nm}$ )과 지르코니아(연마처리: $110 \mathrm{~nm}$, 암축공기입자: $480 \mathrm{~nm}$ )는 표면처리(연마처리한 평활한 표면, 압축공기 입자연마한 거친 표면)를 달리하여 섬유 아세포의 반응을 비교하였다. 이 연구에서 세포증식정도 를 평가하였는데 티타늄과 지르코니아 표면에 비해 비귀 금속 합금 $(\mathrm{Cr}-\mathrm{Co})$ 과 금합금의 표면에서 상대적으로 낮 은 세포증식을 보이며, 120 시간 배양 후에는 비귀금속 합금 $(\mathrm{Cr}-\mathrm{Co})$ 만 유의하게 낮은 세포증식을 나타내고 티 타늄에서 가장 우수한 반응을 보였다고 보고하였다.

이상의 지대주 재료에 따른 세포반응에 대한 연구들 
을 정리하면, 금합금은 티타늄과 지르코니아에 비해 낮 은 세포증식과 염증상태의 세포 및 기질분비가 관찰되지 만, 표면을 잘 조절하면 충분히 안정적이다. 금합금이 지 대주재료로 적합한지 여부를 결론짓기는 어렵지만 티타 늄과 지르코니아에 비해서는 상대적으로 세포반응이 열 등하므로, 금합금 지대주 주위 연조직에서 반복적인 염 증소견이 관찰되는 경우 티타늄이나 지르코니아 등 다른 지대주 재료로의 교체를 고려하는 것이 낫다. 티타늄과 지르코니아는 모두 화학적으로 안정되어 있으며 우수한 생체적합성을 가져 금합금이나 비귀금속 합금에 비해 우 수한 세포반응을 보이지만 물리적, 화학적 성질 차이가 존재할 수 있어 구체적인 반응은 조건에 따라 차이가 있 다. 지대주의 표면거칠기에 따른 세포반응은 세포종류에 따라 다른데, 결합조직의 생성에 관여하는 섬유아세포는 평활한 표면에서 부착이 촉진되나 거친 표면에서 증식이 우세하며, 이와 반대로 상피세포는 평활한 표면에서 접 착과 증식이 모두 우세하게 나타나는 특성을 보였다. 따 라서 표면거칠기에 따른 세포의 반응은 세포의 부착메커 니즘에 대한 종합적인 이해와 고려가 필요하다 하겠다.

\section{지대주에 대한 박테리아 부착}

임플란트 주위염은 감염과 그로 인한 염증반응으로 발 생한 임플란트 주위 골소실로 정의한다. ${ }^{15}$ 임플란트 주위 염에 관여하는 박테리아 종은 자연치의 치주염에 관여하 는 박테리아 종과 유사하다고 알려져 있다. ${ }^{16}$ 세균막의 형성과 박테리아의 집락화 과정은 타액에 의해 획득피 막(acquired pellicle)이 표면에 형성되면 이를 매개로 하 여 초기 집락 박테리아 종인 Streptococci와 Actinomyces군 이 부착하고 부착상태를 유지하게 되면 치주질환과 연관 된 혐기성 세균인 Fusobacterium, Porphyromonas, Prevotella, Capnocytophaga군 등이 Streptococci군을 매개로 부착하여 치주염이나 임플란트 주위염으로 진행된다. ${ }^{17}$ 임플란트 의 각 구성요소인 상부 보철물, 지대주, 임플란트 자체와 각각의 연결부가 모두 치태축적의 대상이 되며, 이 때 재 료의 표면거칠기, 표면에너지, 표면의 화학적 조성, 디자 인 특성 등이 영향을 미치게 된다. 이 중 임플란트 지대주 에 대한 박테리아 부착은 초기부착 시 획득피막을 매개 로 하여 반데르발스힘(Van der Waals force)과 정전기적 반발력(electrostatic repulsive force)의 작용에 의해 이뤄 지게 된다. 박테리아 집락화의 주요 원인은 임플란트와 지대주 간의 미세간극(micro-gap)과 과도한 표면거칠기,
임플란트의 기계적, 화학적 표면처리, 과풍융된 보철물 형태 등이며, 지대주 재료와 관계된 특성 중 표면거칠기, 젖음성, 표면자유에너지가 영향을 미친다. 그 외 국소적 개체요인으로는 혈장의 구성성분(plasma constituents), 타액 내의 이온성분(salivary ions), 지대주 표면에 부착한 단백질 성분 등이 영향을 관여한다. ${ }^{17}$

치태축적과 관련하여 티타늄과 지르코니아를 비교하 는 다양한 연구가 존재한다. Scarano 등 ${ }^{18}$ 은 티타늄과 지 르코니아의 치태축적을 비교하여 지르코니아에 비해 티 타늄 표면에서 구균(cocci)과 막대균(rod, filament)형상 의 박테리아가 넓은 면적으로 축적되는 결과를 보인다 고 하였다. 박테리아의 초기 부착이 전기적 성질의 영향 을 받으므로 티타늄과 지르코니아의 전기전도성(electric conductivity)의 차이에 의해 티타늄에서 더 많은 치태축 적을 보인다고 설명하였다. ${ }^{18}$ Van Brakel 등 ${ }^{19}$ 은 티타늄 과 지르코니아에서 박테리아의 집락화와 점막에 대한 영 향을 평가하였다. 3 개월 후 임상적인 지표에서 지르코니 아가 더 작은 치주낭깊이(pocket depth)만 나타냈을 뿐 그 외는 큰 차이를 보이지 않았다. 이 연구에서 치주질환 의 원인이 되는 박테리아 종들의 표면 증식을 비교 시 표 면에 따른 차이는 존재하지 않았으며, 유의한 차이를 보 이지 않은 원인이 Bollen과 Quirynen 등 ${ }^{20}$ 이 제시한 세포 부착은 증진시키면서 박테리아부착은 감소시키는 최적 거칠기인 $0.2 \mu \mathrm{m}$ 의 표면을 부여했기 때문이라고 설명하 였다. Salihoglu 등 ${ }^{21}$ 은 수적시험(water drop test)을 통해 티타늄과 지르코니아의 표면자유에너지를 비교했을 때, 지르코니아에서 더 낮은 표면자유에너지를 보였으나 치 주질환 원인균(A. actinomycetemcomitans, P. gingivalis)의 부 착 비교 시 두 재료 간에 유의한 차이가 없었다고 보고 하였다. De Avila 등른 티타늄과 지르코니아 지대주에 서 혐기성 치주질환 원인균(P. gingivalis, F. nucleatum)의 세 균막 형성을 비교하였다. 두 종류의 지대주 표면특성 분 석 시, 거칠기는 $0.2 \mu \mathrm{m}$ 로 유사한 평균 표면거칠기값을 나타내며 접촉각 비교 시 수적시험에서 모두 50도 이하 로 친수성의 표면을 갖고 있었으며 비극성의 요오드화메 틸렌(diiodomethane)으로 평가 시 티타늄이 가장 소액 성(lyophobic)을 보였다. 박테리아의 증식과 관련하여 두 재료에 따른 차이는 없었지만 부착형태를 공촛점 레이저 현미경으로 관찰 시 F. nucleatum이 티타늄 표면에서 상대 적으로 많이 관찰되며 생물량(biomass) 측정 시에는 지 르코니아 표면에서 적은 박테리아 증식을 보였다. 티타 늄과 지르코니아 두 재료는 대부분 실험에서 우수한 반 
응을 보이며 티타늄이 지르코니아에 비해서 높은 박테리 아 부착을 보이는 경우도 존재하였는데 이는 전기전도성 과 표면에너지 차이로 인해 발생한 것으로 생각할 수 있 다. Yamane 등 $^{23}$ 은 티타늄, 지르코니아. 알루미나, 금합 금 디스크를 구강 내에 위치시켜 박테리아의 부착을 평 가하였다. 그 결과 재료간의 차이는 없었고 대상숙주에 따른 차이만 존재하였다. $\mathrm{Kim}$ 등 $^{24}$ 은 초기 부착에 관여 하는 Streptococci 종의 티타늄, 지르코니아, 알루미나-지르 코니아, 금합금에 대한 부착을 비교하였다. 표면거칠기 는 모두 $5 \mathrm{~nm}$ 미만으로 평활한 표면이며 접촉각에 대해 서는 금합금이 가장 높은 극성과 낮은 비극성을 보이며 높은 표면에너지를 가졌다. 박테리아 부착 평가 시, 금합 금에서 가장 높은 초기 박테리아의 집락화가 나타났는 데, 이는 높은 극성의 표면 자유에너지로 인해 강한 박테 리아의 부착이 일어난 것으로 보인다. 다른 재료 간에는 유의한 차이를 보이지 않았다.

같은 티타늄 표면이라고 하더라도 표면성질에 따라 박
테리아 부착은 다른 양상을 나타낼 수 있다. $\operatorname{Kim}$ 등 $^{25}$ 은 압축공기입자연마를 한 표면과 마그네슘을 주입하여 화 학적으로 표면을 개질한 티타늄에서 동일하게 P. gingivalis 의 부착이 증가한다고 하였다(Fig. 3). 이러한 부착이 박 테리아에 대한 특이적(specific) 성질에 의한 것인지 비특 이적(non-specific) 성질에 의한 것인지 명확하지는 않다. Kang 등 $^{26}$ 은 마그네슘과 칼슘을 주입한 티타늄표면에 대한 P. gingivalis와 F. nucleatum의 부착을 연구하여 이온 의 종류나 박테리아의 종류에 의한 특이적 부착이 아니 라 양이온과 박테리아 세포벽의 음이온이 부착하는 정전 기적 결합에 의한 비특이적 부착을 주장하였다(Fig. 4).

이러한 내용들을 정리해보면 금합금의 경우 높은 극성 의 표면에너지와 낮은 비극성의 표면에너지로 인해 초기 박테리아종 (Streptococci)의 집락화가 상대적으로 크게 나 타났다. 티타늄과 지르코니아는 대부분 연구에서 유사 하게 낮은 박테리아 축적도를 나타냈으나 일부 연구에서 티타늄이 지르코니아에 비해 높은 박테리아 축적도를 보
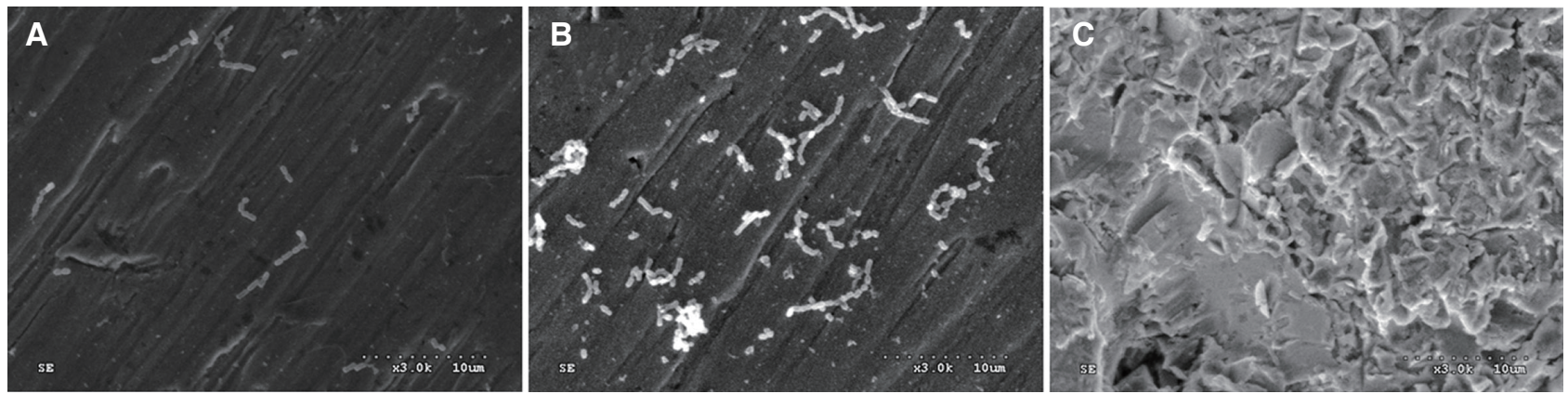

Fig. 3. $P$. gingivalis attachment on the different surface treatments. (A) Machined-turned surface, (B) Magnesium ion implanted surface, (C) Sandblasted with magnesium ion implanted surface. Chemical modification and surface roughening induced increased bacterial attachment.
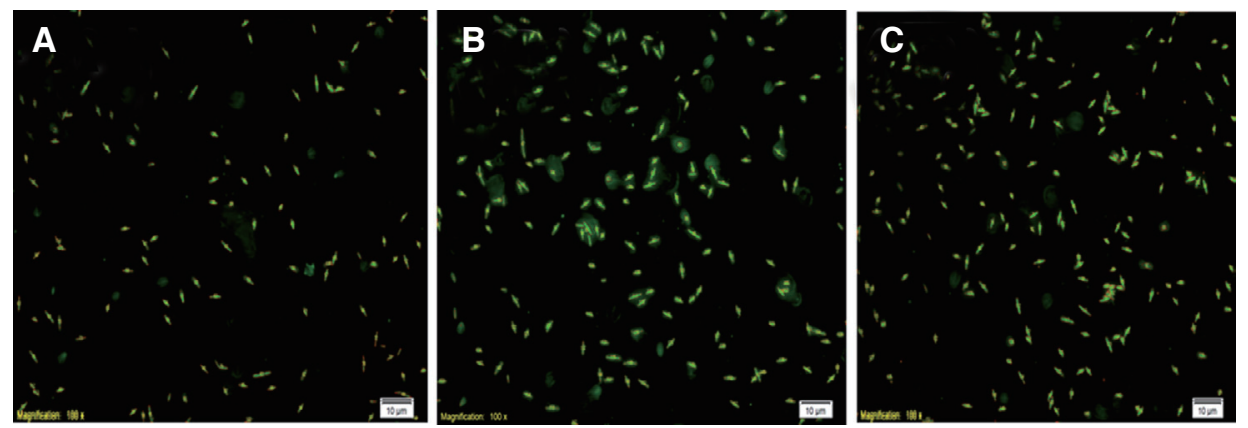

Fig. 4. Fusobacterium attachment on the different ion types. (A) Machined-turned surface, (B) Calcium ion implanted surface, (C) Magnesium ion implanted surface. Chemical modification regardless of the ion type induced increased bacterial attachment. It means non-specific bacterial attachment. 
였는데 이는 티타늄의 전기전도도와 표면 자유에너지, 친 수성이 지르코니아에 비해 높은 것이 원인으로 보인다. 티타늄의 표면거칠기가 증가하거나 화학적인 개질에 의 해서도 박테리아 축적도가 높아질 수 있으므로 구강 내 에 노출되는 부분은 가급적 평활한 표면을 지니고 재료 자체의 성질만 가지는 것이 박테리아에 좀 더 저항할 수 있는 방법이 될 것이다.

\section{지대주에 대한 표면처리의 영향}

나노처리된 지대주 표면은 그 처리된 표면의 크기로 인 해 세포반응을 촉진시키면서 박테리아의 부착은 증가시 키지 않는 특성을 가지는 것으로 알려져 최근 나노 단위 의 표면처리법에 대한 연구가 많이 진행되고 있다. 다양 한 표면처리 방법 중 표면 양극산화와 레이저 조사를 이 용한 방법에 대한 연구가 많이 이루어졌다.

양극산화와 관련하여 Sawase 등 ${ }^{27}$ 은 상용화된 5 개 제조 사의 지대주를 표면분석을 통해 비교하였다. Bråmemark (Nobel Biocare, Gothenburg, Sweden), Astra (AstraTech, Molndal, Sweden), IMZ (Friatec, Manngeim, Germany), Steri-Oss (DiamoDent, Anaheim, USA) 등의 4개 지대 주 표면은 기계절삭된 티타늄 표면으로 확대하였을 때 절삭흔(turning mark)이 관찰되나 POI (Kyocera, Kyoto, Japan) 지대주는 양극산화처리를 한 티타늄합금으로 등 방성(isotropic) 표면을 보였다. 5 개의 지대주에서 유사 한 표면거칠기를 보이지만 화학적 조성 분석 시 POI 지 대주만 양극산화에 의해 상대적으로 두꺼운 산화막층 을 보였다. 이는 세포 및 박테리아의 부착과 관계되어 영 향을 미칠 수 있다. Guida 등 $^{28}$ 은 양극산화처리가 티타 늄의 표면특성과 치은섬유아세포에 미치는 영향을 기계 절삭된 표면과 비교하여 평가하였다. 표면거칠기 분석에 서 Sa값은 $0.2-0.3 \mu \mathrm{m}$ 로 두 표면이 유사한 값을 나타냈 지만 Sdr값은 산화된 티타늄 표면에서 유의하게 높은 값 을 나타냈다. 이는 산화된 표면이 비슷한 표면거칠기이 지만 나노단위에서는 복잡한 표면특성을 가지는 것으로 볼 수 있다. 섬유아세포의 증식 형태를 살펴보면, 산화된 표면에서 더 발달된 부착형태인 사상위족(filopodia), 층 상위족(lamellipodia)형태로 세포분화가 일어나 우수한 세포부착 형태를 보였고 섬유아세포의 세포골격(actin cytoskeleton)의 형광염색 관찰 시 산화된 표면에서 방향 성을 갖지 않는 더 퍼진 형태의 우수한 부착이 관찰되었 다. 세포증식분석에서도 산화된 표면에서 세포증식이 유
의하게 높게 나타났고 7일 배양 시에 산화된 표면에서 제 1 형 콜라겐 합성이 유의하게 높은 값을 보였다. 정리하면 티타늄 표면의 양극산화처리는 세포부착의 질을 우수하 게 하며 세포증식과 세포부착과 관계된 제 1 형 콜라겐의 합성을 증진시킬 수 있다.

레이저 조사를 이용한 표면처리방법에 대한 연구를 살 펴보면 Lee 등 $^{29}$ 은 레이저를 이용한 나노크기의 홈(nanodimple) 형성이 상피세포와 섬유아세포의 부착에 미치 는 영향에 대해 조사하였다. 나노홈을 형성한 군이 대조 군보다 상피세포의 부착과 섬유아세포의 증식을 증진시 켰다. 주사전자현미경을 통해 세포의 부착형태를 관찰 한 결과 나노홈을 형성한 표면에서 사상위족과 층상위 족 형상의 우수한 세포부착이 관찰되었다. 이를 통해 레 이저를 이용한 나노홈의 형성은 상피의 초기부착을 증진 시키며 섬유아세포의 증식을 증진시키고 부착의 질을 향 상시킨다고 할 수 있다. 레이저를 이용한 표면의 microgroove형성 방법인 laser-lok (BioHorizon, Birmingham, USA) 표면처리에 대한 연구를 살펴보면, Pecora 등 $^{30}$ 은 레이저 처리한 표면에서 더 작은 치주낭깊이 및 적은 변 연골 소실을 보였다고 보고하였고 Nevins 등 ${ }^{31}$ 은 레이저 처리한 표면에서 접합상피와 결합조칙의 부착이 우수하 게 관찰되었다고 보고하였다. 이러한 레이저 표면처리는 치은 연조직반응을 향상시켜 임플란트 주위 연조직 부착 에 의한 점막봉쇄효과를 증진시키므로 임상적인 의의를 지닐 수 있다. $\mathrm{Li}$ 등 $^{32}$ 은 은나노입자를 포함하는 티타늄의 항균작용에 대한 연구를 진행하였다. 그 결과 뛰어난 항 균작용 및 박테리아 부착을 막는 효과를 확인하였으며 섬유아세포의 분화를 촉진하는 것을 확인하였다. 그 외 에도 다양한 항균성 물질을 처리하는 방법에 대한 연구 도 진행되고 있으나 아직 그 효율성과 적용성에 대해서 는 완전히 해결되지 않았다.

지대주의 표면처리방법과 그 영향을 요약하면 양극산 화처리는 표면의 지형학적 특성과 화학적인 성분을 변화 시킴으로써 세포반응 변화를 유도하여 생체적합성을 변 화시킬 수 있으며, 레이저 표면처리는 조직과 반응하는 미세구조를 변화시켜 연조직반응을 향상시킴으로써 계 면으로의 섬유조직 침범을 막아 장기적인 임플란트 주위 조직의 안정성을 증진시킬 가능성이 있다. 그 외에도 나 노단위의 표면처리를 이용하는 방법도 점차적으로 증가 하고 있어 더 많은 연구가 필요하다. 


\section{지대주 연결방법에 따른 연조직의 변화}

지대주를 연결하는 방식에 따라서도 주변 연조직은 영 향을 받게 되는데 Hermann 등 ${ }^{33}$ 은 지대주와 임플란트 간의 미세간극(micro-gap) 및 반복적인 착탈이 골수준 에 미치는 영향을 비교하여, 미세간극의 크기나 위치보 다는 반복적인 착탈에 의해 주변골상실이 유발된다고 하 였다. 대부분의 상용 임플란트는 미세간극이 연조직 상 부이건, 하부이건 간에 존재할 수 밖에 없으며 이를 통해 세균이나 염증성 삼출물이 통과하지만 이로 인해 특별한 연조직의 염증반응을 유발하지 않기 때문에 지대주에 안 정적으로 부착된 연조직과의 결합이 반복적인 착탈에 의 해 파괴되기 때문에 이러한 결과가 나타난 것으로 보인 다. Alves 등 $^{34}$ 은 한 번 제거한 지대주 주위에 완벽한 치 유가 되려면 최소 6 개월이 필요하다고 하여 가급적 착탈 을 최소화 할 것을 권유하였다. 초기 치유과정 중의 반복 적인 지대주 착탈은 더 파괴적인 결과를 나타낼 수 있으 므로 ${ }^{35}$ 더 주의를 기울여야 할 것이다.

Platform switching이 주변골 수준에 긍정적인 영향을 끼친다는 것은 널리 알려진 사실이다. Farronato 등 ${ }^{36}$ 은 그 원인이 연조직의 두께에 의한 것이라고 하면서 platform switching을 통해 상피세포의 길이가 $1 \mathrm{~mm}$ 가량 줄어든
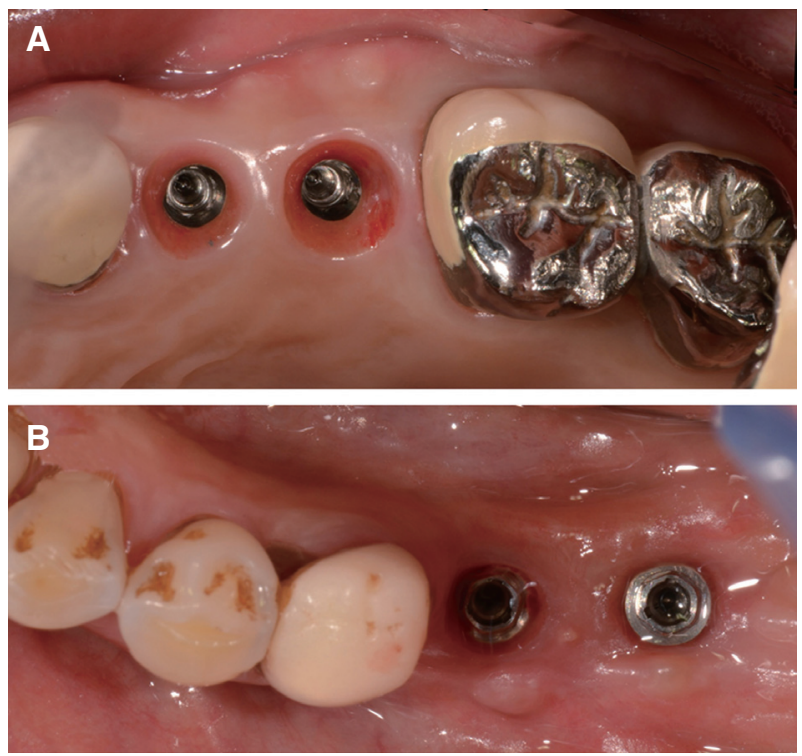

Fig. 5. Soft tissue reaction on the different implant connection types in one patient. (A) Soft tissue reaction on the internal connection type in the maxilla, (B) Soft tissue reaction on the external connection type in the mandible.
다고 하였다. 따라서 원추형 연결을 가지는 내부연결형 임플란트는 근본적으로 platform switching을 가지므로 전반적으로 연조직반응이 우수한 경향을 띄게 된다(Fig. $5)$.

연조직을 통과하는 부위(transmucosal part)의 형태도 연조직반응에 영향을 미친다. Huh 등 ${ }^{37}$ 은 직선형과 오목 한 형태의 연조직 통과부위를 가진 지대주를 비교하여 오 목한 형태가 상피세포의 길이를 줄이는데 기여한다고 하 였다. 하지만 $\operatorname{Kim}$ 등 $^{38}$ 은 오목한 형태가 결합조직의 부착 을 획득하기 유리한 형태이기는 하지만 실제 상피세포의 길이는 다르지 않다고 하여 아직 연조직 통과부위의 형태 에 대한 확실한 결론을 내리기는 어려운 실정이다.

지금까지 연구된 연조직반응의 영향요인을 Iglhaut 등 ${ }^{39}$ 은 다음과 같이 정리하였다. 먼저, 임플란트의 3 차원적인 위치로 인접치와 최소 $1.5-2.0 \mathrm{~mm}$ 간격이 필요하며, 협 측보다 설측으로 위치하는 것이 유리하다. 둘째, 임플란 트와 지대주 연결이 platform switching 형태일 때 연조 직 보존에 더 유리하다. 셋째, 협측 골두께가 $1.8 \mathrm{~mm}$ 이 상이 되어야 하므로 전치부에서 보통 직경 $4 \mathrm{~mm}$ 이하의 임플란트가 적절하다. 넷째, 치은두께가 $1-1.3 \mathrm{~mm}$ 이상 의 두꺼운 유형(thick biotype)일 때 유리하며 마지막으로 $3 \mathrm{~mm}$ 이상의 부착점막이 필요하다고 하였다. 전반적으 로 연조직 보존을 위해서는 두껍고 건강한 연조직을 확 보하는 것이 가장 중요하다고 피력하고 있는 것이다.

\section{맞춤형 지대주 제작 후 세척 방법}

최근 $\mathrm{CAD} / \mathrm{CAM}$ 방식을 이용한 맞춤형 지대주의 사 용이 증가하면서 지대주 절삭과정 후 표면에 잔류하는 미세한 입자에 대한 우려가 증가하고 있다. 이러한 잔류 입자는 직접적으로는 초기단계의 연조직 치유에 영향을 미쳐 임플란트-연조직 계면의 염증반응을 유발할 수 있 고 미세한 오염물질에 의해 박테리아의 부착과 파골세 포의 활동성이 증가하여 변연골 소실로 이어질 수 있다. 간접적으로는 박테리아 축적의 요인이 되어 연조직의 안 정성을 저하시키거나 임플란트-지대주 연결부의 부적합 (misfit)을 유발하여 기계적 안정성을 저하시킬 수도 있 다. 하지만 현재까지 맞춤형 지대주의 제작 후 세척방법 에 대한 연구는 많지 않은 실정이다. 현재 제안되는 방법 은 스팀분사, 초음파 세척, 아르곤 플라즈마 처리가 있다.

Canullo 등 ${ }^{40}$ 은 맞춤형 티타늄 지대주 절삭 후 위의 3 가지 표면처리 방법에 따른 표면특성을 주사전자현미경 
을 통해 관찰하였다. 스팀분사는 $2-3 \mu \mathrm{m}$ 의 미세 입자를 제거하지 못하였고 박테리아의 증식도 관찰되었다. 반면 초음파세척과 아르곤 플라즈마를 이용한 세척은 효과적 으로 표면의 오염원을 제거하였다. Gehrke 등 ${ }^{41}$ 은 지르 코니아를 이용한 맞춤형 지대주 제작 후 스팀분사와 초 음파 세척 방법을 비교하였는데, 초음파 세척은 비교적 효과적으로 오염원을 제거하였으나 완벽하지는 않았고 스팀분사는 많은 잔사가 표면에 남아 부적절한 세척방 법으로 확인되었다. 아르곤 플라즈마처리로 인해 지대주 표면이 친수성을 띄게 되어 젖음성이 증가하는 것이 우수 한 세척의 기전으로 제시되었다. ${ }^{41}$

맞춤형 지대주의 후처리 방법 중 스팀분사 방식은 탄 소나 티타늄과 같은 불완전한 미세입자의 제거에 의해 임플란트 주위 조직의 안정성에 영향을 미칠 수 있다. 반 면 초음파 세척 방식은 수용성 물질과 유기물을 효과 적으로 제거할 수 있으며, 이를 위해서 항균성 세정제 (antibacterial detergent)와 아세톤 그리고 에틸알코올 을 용매로 한 3단계 초음파 세척을 제안하고 있다. 새롭 게 제시되는 아르곤 플라즈마 처리는 가장 효과적으로 표면의 오염잔사를 제거하였으며 표면의 원자 및 분자구 조의 변화를 일으켜 오염물질의 제거뿐만 아니라 세포 의 반응도 증진시킬 수 있는 방법이다. CAD/CAM 방 식의 지대주 중 진공포장된 것은 이러한 세척처리가 되 었다고 추정할 수 있으나 현재 이용되고 있는 대부분의 $\mathrm{CAD} / \mathrm{CAM}$ 지대주는 유기용매 처리만하여 사용되고 있 다. Canullo 등 ${ }^{42}$ 은 아르곤 플라즈마 방식의 후처리에 비 해 스팀분사방식 지대주를 체결한 경우에 임플란트 주변 골소실이 더 크다고 하였다. 물론 이 연구에서 그 차이는 크지 않으나 임상적으로 문제를 유발할 가능성을 완전히 배제할 수 없으므로 이러한 세척이 끼치는 임상적인 결과 에 대한 추가적인 연구가 필요할 것으로 보인다.

\section{결론 및 요약}

임플란트 지대주는 세포와 연조직 부착 및 증식에 적 절한 표면을 가져 하방 조직을 보호하고, 임플란트 주위 염에 관여하는 박테리아 종의 부착을 억제하는 적절한 표면성질을 가져야 한다. 금합금의 경우 낮은 표면에너 지를 지니며 안정적인 치과재료로 수복물에 널리 사용되 고 있으나, 티타늄과 지르코니아와 비교 시 세포반응과 연조직의 조직학적 소견 및 박테리아 부착에서 상대적으 로 취약한 결과를 보였다. 티타늄과 지르코니아는 물리,
화학적으로 안정적이며 생체적합성이 뛰어나 우수한 반 응을 보여 금합금에 비해서 효과적으로 임플란트 주위 조직을 보호할 수 있을 것으로 보인다. 임플란트 지대주 의 성질개선을 위한 부가적인 표면처리 방법들이 제안되 고 있으며 그 방법으로 양극산화, 레이저 표면처리와 같 은 나노단위의 표면처리방법과 살균작용을 갖는 생체분 자를 이용한 다양한 방법들이 제시되고 있으며 이에 대 한 더 많은 연구들이 필요할 것으로 보인다. 지대주의 형 태나 연결방법도 연조직반응에 영향을 끼치며 platform switching 및 오목한 형태를 가진 지대주를 사용하고 반 복적인 지대주착탈을 피해야 한다. 맞춤형 지대주의 사 용이 증가하면서 지대주의 제작과정에서 발생하는 잔류 입자 등에 의한 연조직염증과 변연골소실에 대한 우려가 증가하고 있으나 이에 대한 연구는 부족한 실정이다. 지 대주 제작 후의 세척방법으로 스팀분사는 부적절하며 항 균성 세정제와 아세톤 및 에틸알코올 등의 다양한 용매 를 이용한 초음파세척 방식이 적절하다. 표면세척뿐만 아니라 세포반응의 증진까지 기대할 수 있는 아르곤 플 라즈마 처리 등과 같은 다양한 방법들에 대한 추가적인 연구가 필요할 것으로 사료된다.

\section{ORCID}

Young-Hoon Lee http://orcid.org/0000-0002-7124-7735

Kyung-Ho Ko http://orcid.org/0000-0002-1260-8844

Yoon-Hyuk Huh http://orcid.org/0000-0003-4072-5199

Chan-Jin Park http//orcid.org/0000-0003-4734-214X

Lee-Ra Cho http://orcid.org/0000-0003-3989-2870

\section{References}

1. Berglundh T, Lindhe J. Dimension of the periimplant mucosa. Biological width revisited. J Clin Periodontol 1996;23:971-3.

2. Nakamura K, Kanno T, Milleding P, Ortengren U. Zirconia as a dental implant abutment material: a systematic review. Int J Prosthodont 2010;23:299309.

3. Nothdurft FP, Fontana D, Ruppenthal S, May A, Aktas C, Mehraein Y, Lipp P, Kaestner L. Differential behavior of fibroblasts and epithelial cells on structured implant abutment materials: a comparison of materials and surface topographies. Clin 
Implant Dent Relat Res 2015;17:1237-49.

4. Tomasi C, Tessarolo F, Caola I, Wennström J, Nollo G, Berglundh T. Morphogenesis of peri-implant mucosa revisited: an experimental study in humans. Clin Oral Implants Res 2014;25:997-1003.

5. Buser D, Weber HP, Donath K, Fiorellini JP, Paquette DW, Williams RC. Soft tissue reactions to non-submerged unloaded titanium implants in beagle dogs. J Periodontol 1992;63:225-35.

6. Berglundh T, Lindhe J, Ericsson I, Marinello CP, Liljenberg B, Thomsen P. The soft tissue barrier at implants and teeth. Clin Oral Implants Res 1991;2:81-90.

7. Abrahamsson I, Berglundh T, Glantz PO, Lindhe J. The mucosal attachment at different abutments. An experimental study in dogs. J Clin Periodontol 1998;25:721-7.

8. Abrahamsson I, Cardaropoli G. Peri-implant hard and soft tissue integration to dental implants made of titanium and gold. Clin Oral Implants Res 2007; 18:269-74.

9. Welander M, Abrahamsson I, Berglundh T. The mucosal barrier at implant abutments of different materials. Clin Oral Implants Res 2008;19:635-41.

10. van Brakel R, Meijer GJ, Verhoeven JW, Jansen J, de Putter C, Cune MS. Soft tissue response to zirconia and titanium implant abutments: an in vivo within-subject comparison. J Clin Periodontol 2012;39:995-1001.

11. Moon YH, Yoon MK, Moon JS, Kang JH, Kim SH, Yang HS, Kim MS. Focal adhesion linker proteins expression of fibroblast related to adhesion in response to different transmucosal abutment surfaces. J Adv Prosthodont 2013;5:341-50.

12. Nothdurft FP, Fontana D, Ruppenthal S, May A, Aktas C, Mehraein Y, Lipp P, Kaestner L. Differential behavior of fibroblasts and epithelial cells on structured implant abutment materials: a comparison of materials and surface topographies. Clin Implant Dent Relat Res 2015;17:1237-49.

13. Kim YS, Ko Y, Kye SB, Yang SM. Human gingival fibroblast (HGF-1) attachment and proliferation on several abutment materials with various colors. Int J Oral Maxillofac Implants 2014;29:969-75.

14. Rutkunas V, Bukelskiene V, Sabaliauskas V, Balci- unas E, Malinauskas M, Baltriukiene D. Assessment of human gingival fibroblast interaction with dental implant abutment materials. J Mater Sci Mater Med 2015;26:169.

15. Lindhe J, Meyle J; Group D of European Workshop on Periodontology. Peri-implant diseases: Consensus Report of the Sixth European Workshop on Periodontology. J Clin Periodontol 2008; 35:282-5.

16. Agerbaek MR, Lang NP, Persson GR. Comparisons of bacterial patterns present at implant and tooth sites in subjects on supportive periodontal therapy. I. Impact of clinical variables, gender and smoking. Clin Oral Implants Res 2006;17:18-24.

17. Subramani K, Jung RE, Molenberg A, Hammerle CH. Biofilm on dental implants: a review of the literature. Int J Oral Maxillofac Implants 2009;24:61626.

18. Scarano A, Piattelli M, Caputi S, Favero GA, Piattelli A. Bacterial adhesion on commercially pure titanium and zirconium oxide disks: an in vivo human study. J Periodontol 2004;75:292-6.

19. van Brakel R, Cune MS, van Winkelhoff AJ, de Putter C, Verhoeven JW, van der Reijden W. Early bacterial colonization and soft tissue health around zirconia and titanium abutments: an in vivo study in man. Clin Oral Implants Res 2011;22:571-7.

20. Bollen CM, Lambrechts P, Quirynen M. Comparison of surface roughness of oral hard materials to the threshold surface roughness for bacterial plaque retention: a review of the literature. Dent Mater 1997;13:258-69.

21. Salihoglu U, Boynuegri D, Engin D, Duman AN, Gokalp P, Balos K. Bacterial adhesion and colonization differences between zirconium oxide and titanium alloys: an in vivo human study. Int J Oral Maxillofac Implants 2011;26:101-7.

22. de Avila ED, Avila-Campos MJ, Vergani CE, Spolidório DM, Mollo Fde A Jr. Structural and quantitative analysis of a mature anaerobic biofilm on different implant abutment surfaces. J Prosthet Dent 2016;115:428-36.

23. Yamane K, Ayukawa Y, Takeshita T, Furuhashi A, Yamashita Y, Koyano K. Bacterial adhesion affinities of various implant abutment materials. Clin 
Oral Implants Res 2013;24:1310-5.

24. Kim HY, Yeo IS, Lee JB, Kim SH, Kim DJ, Han JS. Initial in vitro bacterial adhesion on dental restorative materials. Int J Artif Organs 2012;35:773-79.

25. Kim ML, Jeong CM, Jeon YC, Byon E, Jeong Y, Cho LR. The effects of Mg-ion implantation and sandblasting on Porphyromonas gingivalis attachment. Clin Oral Implants Res 2012;23:245-52.

26. Kang SN, Jeong CM, Jeon YC, Byon ES, Jeong YS, Cho LR. Effects of Mg-ion and Ca-ion Implantations on P. gingivalis and F. nucleatum Adhesion. Tissue Eng Regen Med 2014;11:39-46.

27. Sawase T, Wennerberg A, Hallgren C, Albrektsson T, Baba K. Chemical and topographical surface analysis of five different implant abutments. Clin Oral Implants Res 2000;11:44-50.

28. Guida L, Oliva A, Basile MA, Giordano M, Nastri L, Annunziata M. Human gingival fibroblst functions are stimulated by oxidized nano-structured titanium surfaces. J Dent 2013;41:900-7.

29. Lee DW, Kim JG, Kim MK, Ansari S, Moshaverinia A, Choi SH, Ryu JJ. Effect of laser-dimpled titanium surfaces on attachment of epithelial-like cells and fibroblsts. J Adv Prosthodont 2015;7:138-45.

30. Pecora GE, Ceccarelli R, Bonelli M, Alexander H, Ricci JL. Clinical evaluation of laser microtexturing for soft tissue and bone attachment to dental implants. Implant Dent 2009;18:57-66.

31. Nevins M, Kim DM, Jun SH, Guze K, Schupbach P, Nevins ML. Histologic evidence of a connective tissue attachment to laser microgrooved abutments: a canine study. Int J Periodontics Restorative Dent 2010;30:245-55.

32. Li P, Tong Z, Huo L, Yang F, Su W. Antibacterial and biological properties of biofunctionalized nanocomposites on titanium for implant application. J Biomater Appl 2016 ;31:205-14.

33. Hermann JS, Schoolfield JD, Schenk RK, Buser D, Cochran DL. Influence of the size of the microgap on crestal bone changes around titanium implants. A histomertric evaluation of unloaded non-submerged implants in the canine mandible. J Periodontol 2001;72:1372-83.

34. Alves CC, Muñoz F, Cantalapiedra A, Ramos I, Neves M, Blanco J. Marginal bone and soft tissue behavior following platform switching abutment connection/disconnection-a dog model study. Clin Oral Implants Res 2015;26:983-91.

35. Iglhaut G, Becker K, Golubovic V, Schliephake H, Mihatovic I. The impact of dis-/reconnection of laser microgrooved and machined implant abutments on soft- and hard-tissue healing. Clin Oral Implants Res 2013;24:391-7.

36. Farronato D, Santoro G, Canullo L, Botticelli D, Maiorana C, Lang NP. Establishment of the epithelial attachment and connective tissue adaptation to implants installed under the concept of "platform switching": a histologic study in minipigs. Clin Oral Implants Res 2012;23:90-4.

37. Huh JB, Rheu GB, Kim YS, Jeong CM, Lee JY, Shin SW. Influence of Implant transmucosal design on early peri-implant tissue responses in beagle dogs. Clin Oral Implants Res 2014;25:962-8.

38. Kim S, Oh KC, Han DH, Heo SJ, Ryu IC, Kwon $\mathrm{JH}$, Han $\mathrm{CH}$. Influence of transmucosal designs of three one-piece implant systems on early tissue responses: a histometric study in beagle dogs. Int J Oral Maxillofac Implants 2010;25:309-14.

39. Iglhaut G, Schwarz F, Winter RR, Mihatovic I, Stimmelmayr M, Schliephake H. Epithelial attachment and downgrowth on dental implant abutments-a comprehensive review. J Esthet Restor Dent 2014;26:324-31.

40. Canullo L, Micarelli C, Lembo-Fazio L, Iannello G, Clementini M. Microscopical and microbiologic characterization of customized titanium abutments after different cleaning procedures. Clin Oral Implants Res 2014;25:328-36.

41. Gehrke P, Tabellion A, Fischer C. Microscopical and chemical surface characterization of CAD/ CAM zirconia abutment after different cleaning procedures. A qualitative analysis. J Adv Prosthodont 2015;7:151-9.

42. Canullo L, Peñarrocha D, Clementini M, Iannello G, Micarelli C. Impact of plasma of argon cleaning treatment on implant abutments in patients with a history of periodontal disease and thin biotype: radiographic results at 24-month follow-up of a RCT. Clin Oral Implants Res 2015;26:8-14. 


\section{임플란트 지대주와 임플란트 주위 연조직의 반응에 관한 고찰}

\section{이영훈, 고경호, 허윤혁, 박찬진, 조리라*}

강릉원주대학교 치과대학 치과보철학교실 및 구강과학연구소

지대주의 재료와 표면에 따라 연조직반응이 다르고 임플란트 주위염의 원인이 될 수 있다. 티타늄과 지르코니아는 우수 한 생체적합성을 가져 안정적인 연조직반응을 보이고 금합금은 표면상태에 따라 연조직반응이 다르게 나타난다. 같은 재료라도 표면특성에 따라 연조직반응이 영향을 받는다. 표면거칠기 증가는 박테리아 부착을 유발하므로 연조직과 접 촉하는 부분은 평활한 표면을 가져야 한다. 추가적인 표면처리를 통해 박테리아의 부착은 증가시키지 않으면서 세포반 응을 촉진시킬 수 있다. 지대주의 형태 및 반복착탈도 연조직반응에 영향을 줄 수 있다. 초음파 세척과 아르곤 플라즈마 처리는 비교적 효과적으로 맞춤형 지대주의 잔류 미세입자를 제거할 수 있는 방법이다.

(구강회복응용과학지 2016;32(4):263-73)

주요어: 지대주 재료; 표면처리; 세포반응; 박테리아 부착; 맞춤형 지대주

*교신저자: 조리라

(25457)강원도 강릉시 죽헌길 7 강릉원주대학교 치과대학 치과보철학교실 및 구강과학연구소

Tel: 033-640-3153 | Fax: 033-640-3103 | E-mail: lila@gwnu.ac. kr

접수일: 2016년 9월 13일 | 수정일: 2016년 12월 5일 | 채택일: 2016년 12월 8일 